\title{
The Effect of Tax Minimization and Exchange Rate on Transfer Pricing Decisions with Leverage as Moderating
}

\author{
Diah Kumala Devi*1 and Trisni Suryarini ${ }^{2}$ \\ ${ }^{1}$ PT Nusantara Building Industri, Central Java, Indonesia \\ ${ }^{2}$ Accounting Department, Faculty of Economics, Universitas Negeri Semarang
}

\section{ARTICLE INFO}

\section{Article History:}

Received January $2^{\text {nd }}, 2020$

Accepted June $30^{\text {th }}, 2020$

Available July $30^{\text {th }}, 2020$

Keywords:
transfer pricing; tax
minimization; exchange rate;
leverage

\begin{abstract}
The aims of this research are to analyze and to find empirical evidence about the effect of tax minimization and exchange rate on company decision of transfer pricing with leverage as moderating variable. The population of this research was mining companies which listed in Indonesia Stock Exchange (IDX) over the period 2013 to 2018 from 45 companies. The sampling technique used purposive sampling. Eighteen companies were selected with 65 units analysis were obtained. In addition, data was analyzed using descriptive statistics and inferential statistics using Moderated Regression Analysis (MRA). The data was processed by IBM SPSS Statistics 21 software. The results show that tax minimization and exchange rate have positive and significant effect on transfer pricing. Leverage does not moderate the effect of tax minimization on transfer pricing but leverage significantly moderate the effect of exchange rate on transfer pricing. The conclusion of this research is transfer pricing decision will be higher when tax minimization and exchange rate be higher, but leverage can moderate the effect of exchange rate to transfer pricing.
\end{abstract}

(C) 2020 Published by UNNES. This is an open access article under the CC BY license (http://creativecommons.org/licenses/by/4.0/)

\section{INTRODUCTION}

Company is a profit-oriented entity, so all activities carried out will aim to obtain maximum profit. Efforts to realize this goal, company does tax planning, according to (Zatun \& Kiswanto, 2015) high tax burden will encourage companies to make efficient their tax payments, because tax is one element of profit reduction. Transfer pricing is one of the methods of corporate tax planning. Suandy (2017) defined transfer pricing as an effort to save tax burden by tactics among others shifting profits to countries with low tax rates.

Different tax rates between countries make a gap for companies to do transfer pricing. Transfer pricing can be done by companies by selling goods and / or services resulting from production to affiliated companies operate in countries with low tax jurisdiction at lower prices, so the profits of companies with high tax jurisdictions become low and conversely the profits of companies with low tax jurisdictions become high (Barker et. al., 2017). However, the overall profit earned by companies become higher because the total amount of tax paid

\footnotetext{
*E-mail:diahkumala21@gmail.com

_Address: Jln Raya Semarang Demak KM 17, Central Java, Indonesia
}

is lower than it should be.

Tax is a major component of state revenue that continues to be increased so that national development can be implemented (Nursheha et al., 2014). However, transfer pricing which is increasingly aggressive done is able to curb state tax revenues. The result of research by the United Nations Conference on Trade and Development (UNCTAD), developing countries lose more than $\$ 100$ billion annually due to transfer pricing. Furthermore, annual data on Global Financial Integrity in Indonesia has the potential to lose tax revenue due to transfer pricing reaching $\mathrm{Rp} 100$ trillion each year.

Many Indonesian companies do transfer pricing with affiliated companies in countries that have low tax rates. One of the cases that attracts attention is the case of transfer pricing by PT Adaro Energy Tbk. PT Adaro Energy sells coal below international standard prices to Coaltrade Service International Pte Ltd, an affiliated company in Singapore. Then by Coaltrade, the coals are resold to the market at market prices. As a result, PT Adaro Energy's profits are small so the taxes paid were also small. The case of tax avoidance through transfer pricing is also carried out by PT Kaltim Prima Coal. Sales to overseas buyers are first diverted to PT Indocoal Resource Limited in the Cayman Islands, and were only 
valued at half the fair price. Next, sales to other buyers are carried out by Indocoal at fair prices. Because of the practice of transfer pricing, the state suffers a loss of $\mathrm{Rp}$ 1.7 trillion.

Search for previous research on transfer pricing, there is still a research gap. Research conducted by Alino \& Lane (2015), Hartati et al. (2015), and Septiyani et al. (2018) prove that tax minimization has a positive effect on transfer pricing. Different results are delivered by Qiansyah (2016) and Putri et al. (2018) that tax minimization has no effect on transfer pricing. Research results by Chan et. al. (2004), Alino \& Lane (2015), and Viviany (2018) find that exchange rate has a positive effect on transfer pricing. Marfuah \& Azizah (2014) and Septiyani et al. (2018) showed contradictory results with previous research results where exchange rate has no effect on transfer pricing. Inconsistencies in the results of the previous studies indicate other variables in the study. Leverage is used as a variable that moderates the effect of tax minimization and exchange rates on transfer pricing.

The purpose of this study is to analyze the effect of tax minimization and exchange rates variables on transfer pricing decisions and find evidence whether leverage is able to moderate the effects of tax minimization and exchange rates on transfer pricing decisions. Previous studies find empirical evidence about the factors that influence transfer pricing, but the results of the studies show inconsistent results. The result inconsistencies of the previous studies indicate the need for other variables to be present. This research presents leverage as a moderating variable.

The originality of this study is in adding leverage as a moderating variable. Leverage is used by management in order to obtain sources of funding for companies. Besides, leverage also functions as a monitoring mechanism for the actions of managers in managing company. Usually, companies with high leverage level will explain information in detail in the financial statements as a way to avoid monitoring costs by creditors compared to companies with low leverage level (Ardyansah \& Zulaikha, 2014). Barnhart \& Rosenstein (1998) state that leverage is one of the external corporate governance mechanisms that functions to carry out supervisory activities. Supervision activities occur because companies with leverage have more obligations to meet creditor information needs. The mechanism that arises because of the leverage makes the loopholes for companies to do transfer pricing will be limited. Herdinata (2014) also finds that leverage is used as a control mechanism in agency conflicts, so as to reduce management's tendency in doing transfer pricing.

Agency theory explained by Jensen \& Meckling (1976) principal as a contract whereby one or more (principals) govern(s) other people (agents) to perform services on behalf of the principals and delegate(s) authority to agents to make the best decision for the principals. However, there are two different interests in which each principal and agent try to prosper themselves. Agency theory is characterized by three assumptions, namely: human nature assumptions, organizational as- sumptions, information assumptions. To mitigate agency problems, principal will conduct a supervisory mechanism. This supervisory mechanism will incur agency costs. Margaretha \& Asmariani (2009) explain some alternatives carried out to reduce agency costs, among others: first increasing ownership of company's shares by management, second through supervisory mechanism from within company, third increasing dividend payout ratio, fourth increasing funding with debt.

Companies will avoid high tax payments because taxes are an element of profit reduction, so companies will do tax minimization, one of which is through transfer pricing in the hope that it can reduce tax burden. Agency theory explains the differences in interests between principals and agents can affect various things, one of which is corporate policy on tax (Ardyansah \& Zulaikha, 2014). Chen et al. (2015) find transfer pricing is influenced by factors that reflect information asymmetry including differences in tax rates. Company's effort to do tax minimization can be done through transfer pricing (Cristea \& Nguyen, 2016), by transferring the income and costs of a company that has a special relationship to companies in other countries with different tax rates (Hartati et al., 2015). Then, the higher the tax minimization, the higher the transfer pricing decision made by the company. Research conducted by Alino \& Lane (2015), Hartati et al., (2015), and Septiyani et al. (2018) show that tax minimization has a positive effect on transfer pricing.

\section{$H_{1}$ : Tax minimization has a positive effect on trans- fer pricing decisions.}

Multinational company transactions cause exchange rate risk due to the exchange of one currency with another currency to make payments. Because of differences in exchange rates, companies experience uncertain payments, exchange rate which is continuously fluctuating result in an uncertain amount of cash needed to make payments. Exchange rate which is fluctuating can affect the transfer pricing in the company (Marfuah \& Azizah, 2014). Agency theory explains the assumption of basic human nature, where humans always avoid risks, then according to Chan et al. (2004) management tends to reduce the risk of exchange rate through the transfer of funds to a strengthening currency through transfer pricing. Some studies like Chan et al., (2004), Alino \& Lane (2015), and Viviany (2018) find evidence that exchange rate has a positive effect on transfer pricing.

\section{$\mathrm{H}_{2}$ : Exchange rate has a positive effect on transfer pricing decisions.}

Tax minimization is a strategy to minimize tax burden. Transfer pricing is often used by many companies as a tool to minimize the amount of tax that must be paid. Through transfer pricing, companies shift their tax obligations from countries with high tax rates to low tax countries (Marfuah \& Azizah, 2014). Agency theory explains that transfer pricing occurs because of a conflict of interest between agent and principal, so the principal will conduct a supervisory mechanism to reduce 
the conflict. Leverage is used to reduce agency conflict by inviting external parties to the company to supervise the company. Leverage applied can be a control for the company through creditors (Herdinata, 2014). The use of leverage will increase manager discipline. This condition will cause companies to carry out tax minimization through transfer pricing will be limited, so it can be said that leverage will moderate the effect of tax minimization on transfer pricing.

\section{$\mathrm{H}_{3}$ : Leverage moderates the effect of tax minimiza- tion on transfer pricing.}

Multinational company transactions relate to differences in the use of currencies and the value of each currency fluctuates relatively along with the time difference. This fluctuating exchange rate will affect the practice of transfer pricing done by the companies (Marfuah \& Azizah, 2014). Companies will use exchange rate to move funds to a stronger currency through transfer pricing. Margaretha \& Asmariani (2009) mentioned one of the alternatives done to reduce agency costs is to increase funding with debt. Leverage shows how much debt is used to finance company assets. The higher the use of leverage, the creditors will conduct increasingly stringent monitoring. In line with this opinion, Barnhart \& Rosenstein (1998) stated that leverage is an external corporate governance mechanism that functions to carry out supervisory activities. Supervisory activities occur because companies with leverage have more obligations to meet creditor information needs. This is able to control corporate management activities in doing transfer pricing, so it can be said that leverage will moderate the effect of exchange rates on transfer pricing.

\section{$\mathrm{H}_{4}$ : Leverage moderates the effect of exchange rates on transfer pricing.}

Based on the description of the theoretical framework, the following research model can be presented on Figure 1.

\section{RESEARCH METHODS}

This research was a quantitative study using secondary data. The research design used was a hypothesis testing study. The population in this study were mining companies listed on the Indonesia Stock Exchange (IDX) for the period 2013 - 2018. The sampling technique used purposive sampling technique with the aim to obtain data in accordance with the criteria needed for research. The sample consisted of 18 companies with 65 units of analysis after being deducted by outlier data. The criteria for selecting a research sample can be seen in Table 1.

The dependent variable of this study was transfer pricing and the independent variables used were tax minimization and exchange rate. This study also used leverage as a moderating variable. The explanation of the research variables can be explained in Table 2 .

Data collection technique used documentation technique. Data was taken from annual reports and financial reports obtained from the official website of the Indonesia Stock Exchange and the official website of the sample company. The analysis technique used in this study was regression analysis using Moderated Regression Analysis (MRA) with the IBM SPSS Statistics 21 application tool. The level of significance used as a basis for decision-making was $5 \%$. The model used in

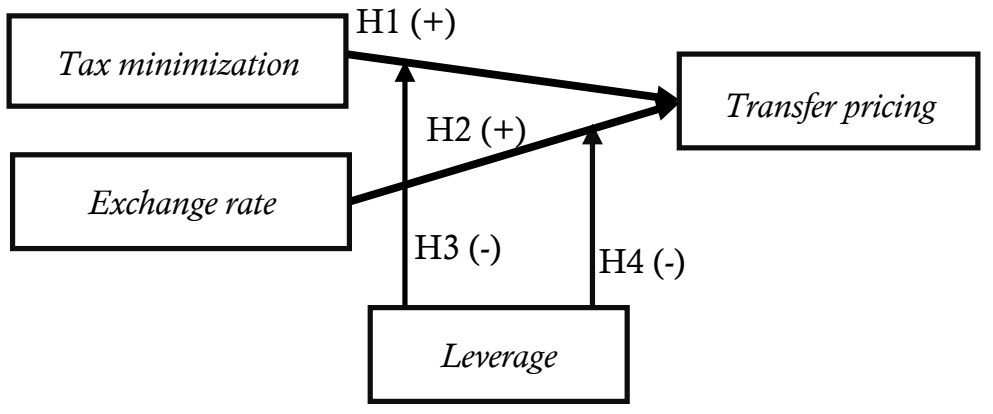

Figure 1. Research Model

Source: Secondary data processed, 2019

Table 1. Research Sampling Criteria

\begin{tabular}{llcc}
\hline No. & \multicolumn{1}{c}{ Criteria } & $\begin{array}{c}\text { Beyond } \\
\text { Criteria }\end{array}$ & $\begin{array}{c}\text { Included } \\
\text { Criteria }\end{array}$ \\
\hline \multirow{2}{*}{ 1. } & Population & Mining companies that have overseas subsidiaries & 45 \\
2. & Mining companies that have related party receivable transactions & $(19)$ & 26 \\
3. & Mining companies that have value of profit (loss) on foreign exchange differences & $(2)$ & 22 \\
4. & Companies that did not experience a loss in a row during the period 2013 - 2018 & $(2)$ & 18 \\
& Total sample companies & & 18 \\
& Number of research analysis units (18 companies x 6 years) & $(43)$ & 65 \\
5. & Mining companies that did not receive tax benefits for the period 2013 - 2018 & 65 \\
& The final number of research analysis units during the period 2013 - 2018 & & 65 \\
\hline
\end{tabular}


Table 2. Operational Definition of Variables

\begin{tabular}{|c|c|c|}
\hline Variables & Definition & Measurement \\
\hline $\begin{array}{l}\text { Transfer pricing } \\
\text { (TP) }\end{array}$ & $\begin{array}{l}\text { The price paid between two companies or } \\
\text { many companies for goods and services sent to } \\
\text { consolidated companies or companies in a special } \\
\text { relationship (Talab et al., 2017) }\end{array}$ & $\begin{array}{c}\text { Related Party Receivables } \\
\text { Total Accounts Receivable } \\
\text { (Sari \& Mubarok, 2018) }\end{array}$ \\
\hline $\begin{array}{l}\text { Tax minimization } \\
(\mathrm{TM})\end{array}$ & $\begin{array}{l}\text { Strategies to minimize tax burden owed through } \\
\text { transfer pricing action and ultimately transfer of } \\
\text { income to countries with low tax rates (Hartati et } \\
\text { al., 2015) }\end{array}$ & $\begin{array}{c}\text { Total Income Tax Expense } \\
\text { Pre-tax profit } \\
\text { (Jaafar \& Thornton, 2015) }\end{array}$ \\
\hline Exchange rate (ER) & $\begin{array}{l}\text { Exchange rate of a currency against current or } \\
\text { future payments, between two different currencies } \\
\text { (Viviany, 2018) }\end{array}$ & $\begin{array}{c}\text { Foreign Exchange Profit and Loss } \\
\text { Pre-tax Profit } \\
\text { (Marfuah \& Azizah, 2014) }\end{array}$ \\
\hline Leverage (LEV) & $\begin{array}{l}\text { The amount of debt used by the company to finance } \\
\text { its assets (Hussain et al., 2016) }\end{array}$ & $\frac{\text { Total Debt }}{\text { Total Asset }}$ \\
\hline
\end{tabular}

\section{Source: Secondary data processed, 2019}

this study can be formulated in equation 1;

$$
\mathrm{TP}=\alpha+\beta_{1} \mathrm{TM}+\beta_{2} \mathrm{ER}+\beta_{3} \mathrm{TM} * \mathrm{LEV}+\beta_{4} \mathrm{ER} * \mathrm{LEV}+\mathrm{e.} .(1)
$$

\section{RESULTS AND DISCUSSIONS}

Descriptive statistics of the 65 companies that become sample during the 2013-2018 period can be explained in Table 3 . The result of the normality test using Kolmogorov-Smirnov shows a significance value of 0.360 . This result is greater than 0.05 so it meets the requirements that the residual data are normally distributed. The result of the multicollinearity test indicates that the tolerance value of each variable is more than 0.1 , meaning that there is no correlation between variables. The VIF value of each variable shows a value of less than 10 , this shows that all independent variables are not correlated. It can be concluded that there is no multicollinearity in the research model. The result of heteroscedasticity test using glejser test shows the significance value of each variable is greater than the significance value of 0.05 . This indicates that heteroscedasticity symptoms do not occur in the research model. Based on the results of the autocorrelation test, it shows the Durbin-Watson value of 2177. The Durbin-Watson value is compared with the table value with a significance level of $5 \%$ of the number of samples (n) 65 and the number of variables (k) 3. From the Durbin-Watson table, we get the value of $\mathrm{dL}=1.5035$ and the value of $\mathrm{dU}=1.6960$. The Durbin-Watson value of 2.177 is greater than the value of $\mathrm{dU}(1.690)$ and less than 4-dU (4 - 1.6960), it is concluded that there is no autocorrelation in the regression model.

The adjusted $\mathrm{R}^{2}$ value on the regression equation is 0.287 which means that $28.7 \%$ of the independent variables can explain the variation of the dependent variable. Transfer pricing variable is influenced by tax minimization and exchange rate variables as well as the interaction of tax minimization and exchange rate variables with leverage as a moderating variable by $28.7 \%$, while the remaining $71.3 \%$ is influenced by other variables not examined in this study. The equation of the hypothesis testing regression model can be explained in Equation 2. Briefly, the results of hypothesis testing can be seen in Table 4 .

\section{$\mathrm{TP}=0.055+0.516 \mathrm{TM}+0.561 \mathrm{ER}-0.018 \mathrm{TM}{ }^{*} \mathrm{LEV}$ $-0.700 \mathrm{ER}^{*} \mathrm{LEV}$.

Table 3. Descriptive Statistics

\begin{tabular}{lrrrrr}
\hline & $\mathrm{N}$ & Minimum & Maximum & \multicolumn{1}{c}{ Mean } & Std. Deviation \\
\hline Transfer pricing & 65 & .0001 & .9359 & .260158 & .2594420 \\
Tax minimization & 65 & .0177 & .9528 & .402429 & .2115588 \\
Exchange rate & 65 & -14.1132 & 1.3278 & -.192822 & 1.7746992 \\
Leverage & 65 & .1384 & 1.0741 & .487285 & .1817257 \\
Valid N (listwise) & 65 & & & & \\
\hline
\end{tabular}

Source: Secondary data processed, 2019

Table 4. Summary of Hypothesis Testing Results

\begin{tabular}{llccc}
\hline & \multicolumn{1}{c}{ Hypothesis } & $\beta$ & Sig. & Decisions \\
\hline $\mathrm{H}_{1}$ & Tax minimization has a positive effect on transfer pricing decisions. & 0.516 & 0.026 & Accepted \\
$\mathrm{H}_{2}$ & Exchange rate has a positive effect on transfer pricing decisions. & 0.561 & 0.016 & Accepted \\
$\mathrm{H}_{3}$ & $\begin{array}{l}\text { Leverage moderates the effect of tax minimization on transfer pricing } \\
\text { decisions. }\end{array}$ & -0.18 & 0.956 & Rejected \\
$\mathrm{H}_{4}$ & $\begin{array}{l}\text { Leverage moderates the effect of exchange rate on transfer pricing } \\
\text { decisions. }\end{array}$ & -0.700 & 0.023 & Accepted \\
\hline
\end{tabular}




\section{The Effect of Tax Minimization on Transfer Pricing}

Tax minimization has a significant positive effect on corporate transfer pricing decisions. This research supports agency theory by Jensen \& Meckling (1976) which confirms that agency theory assumes that all individuals will act in their own interests. Furthermore, Ardyansah \& Zulaikha (2014) explained the difference in interests between principal and agent will affect corporate policy regarding taxes. Companies as profitoriented entities will try to minimize their tax burden (tax minimization) in order to achieve maximum profit. Gupta (2012) stated that companies carries out transfer pricing in order to maximize profits obtained and reduce the obligation to pay corporate taxes. The companies will do tax minimization, one of which is through transfer pricing, so the higher the tax minimization by the companies, the higher the transfer pricing decision taken by the companies. The result of this study is in line with Alino \& Lane (2015), Hartati et al. (2015), and Septiyani et al. (2018) which prove tax minimization has a positive effect on transfer pricing.

\section{The Effect of Exchange Rate on Transfer Pricing}

Exchange rate has a significant positive effect on corporate transfer pricing decision. This research is in accordance with agency theory, Jensen \& Meckling (1976) explained that there is an assumption of human nature that underlies agency theory, which is selfish and tends to dislike risk. Correspondingly, the companies are faced with the economic risk of exchange rate, so they will try to reduce the exchange rate risk by moving funds to a strong currency through transfer pricing (Chan et al., 2004). Cravens \& Shearon (1996) stated to control the risk of gains and losses from foreign currency transactions, the companies will use transfer pricing as a protective fence to deal with changes in exchange rates. Transfer pricing can be used to reduce a company's transaction exposure to the risk of exchange rate changes by moving funds into a strong currency. The result of this study is in accordance with research by Chan et al., (2004), Alino \& Lane (2015), and Viviany (2018) which find evidence of exchange rate has a positive effect on transfer pricing.

\section{The Effect of Tax Minimization on Transfer Pricing with Leverage as Moderating}

Leverage does not moderate the effect of tax minimization on corporate transfer pricing decisions. This study does not support agency theory which explains that leverage will create a supervisory mechanism for the company's operations because the company has an obligation to provide detailed information for creditors. The result of this testing can be explained through positive accounting theory, where the closer a company is to a debt covenant (debt covenant hypothesis) tends to be more likely the company manager chooses an accounting policy that will increase company profits. The company will choose certain accounting policies that can increase profits. Based on the debt covenant hypothesis, a company that has leverage will be more aggressive in doing tax minimization, one of the ways is through transfer pricing. Richardson et al. (2013) explained that debt and / or capital transfers which are partly driven by opportunities for tax arbitration, thus companies involved in leverage for tax purposes are more likely to be aggressive in terms of corporate transfer pricing arrangements. According to Rego (2003) there is a possibility that leverage can act as a substitute for transfer pricing in achieving corporate tax liability reduction. This is done by acquiring debts from group members who are in lowtax areas.

\section{The Effect of Exchange Rate on Transfer Pricing with Leverage as Moderating}

Leverage moderates the relationship between exchange rates and corporate transfer pricing decisions. The company's activities with overseas affiliated companies cause transactions with exchange rate differences where it raises the motivation of companies to use it through transfer pricing by moving funds to a stronger currency in order to obtain overall benefits. However, if at the same time the company has a high level of debt (leverage), it will make the control and supervision process towards the managers not only done by shareholders but also carried out by creditors (Simanjuntak \& Kiswanto, 2015). Barnhart \& Rosenstein (1998) stated that leverage is an external corporate governance mechanism that functions to carry out supervisory activities. Supervisory activities occur because companies with leverage have more obligations to meet creditor information needs. This is able to limit corporate management activities in transfer pricing.

\section{CONCLUSIONS}

The results of this research can be concluded that the decision of the company to do transfer pricing can be even higher when the tax minimization and exchange rate owned are higher, but leverage will reduce corporate transfer pricing decision. That is because leverage has proven to be a mechanism for corporate control and moderate exchange rate relationships in transfer pricing decisions. The government issued Minister of Finance Regulation No. 213 / PMK / 03 in 2016 regarding types of documents and additional information that must be kept by taxpayers who make transactions with related parties, for further research to use the observation period after 2016 so as to reflect the latest trends in transfer pricing.

\section{REFERENCES}

Alino, N. U., \& Lane, S. (2015). A Conceptual Model of the Effects of Taxation, Exchange Rate, and Regulations on the Transfer Pricing Behavior of Multinational Firm Managers. Journal of Comparative International Management, 18(1), 24-36.

Ardyansah, D., \& Zulaikha. (2014). Pengaruh Size, Leverage, Profitability, Capital Intensity Ratio dan Komisaris Independen terhadap Effective Tax Rate (Etr). Diponegoro Journal of Accounting, 3(2), 1-9.

Barker, J., Asare, K., \& Brickman, S. (2017). Transfer Pricing as A Vehicle in Corporate Tax Avoidance. Journal of 
Applied Business Research, 33(1), 9-16.

Barnhart, S. W., \& Rosenstein, S. (1998). Board Composition, Managerial Ownership, and Firm Performance: An Empirical Analysis. The Financial Revvew, 33, 1-16.

Chan, C., Landry, S. P., \& Jalbert, T. (2004). Effects Of Exchange Rates On International Transfer Pricing Decisions. International Business \& Economics Research Journal, 3(3), 35-48.

Chen, C. X., Chen, S., Pan, F., \& Wang, Y. (2015). Determinants and Consequences of Transfer Pricing autonomy: An Empirical Investigation. Journal of Management Accounting research, 27(2), 225-259.

Cravens, K. S., \& Shearon, W. T. (1996). An Outcome-Based Assessment of International Transfer Pricing Policy. International Journal of Accounting, 31(4), 419-443.

Cristea, A. D., \& Nguyen, D. X. (2016). Transfer pricing by multinational firms: New evidence from foreign firm ownerships. American Economic Journal: Economic Policy, 8(3), 170-202.

Gupta, P. (2012). Transfer Pricing: Impact of Taxes and Tariffs in India. The Journal for Decision Makers, 37(4), 29-46.

Hartati, W., Desmiyawati, \& Julita. (2015). Tax Minimization, Tunneling Incentive dan Mekanisme Bonus terhadap Keputusan Transfer Pricing Seluruh Perusahaan yang Listing di Bursa Efek Indonesia. In Simposium Nasional Akuntansi 18 Medan, 241-246.

Herdinata, C. (2014). Mekanisme Kontrol dan Ekspropriasi pada Perusahaan di Indonesia. In Proceedings Forum Manajemen Indonesia 6 Entrepreneurial Management, $1-11$.

Hussain, M., Shahid, H., \& Akmal, M. (2016). Effect of Profitability and Financial Leverage on Capital Structure in Pakistan Textile Firms. Arabian Journal of Business and Management Review, 6(4), 4-7.

Izadinia, N., Foroghi, D., \& Gheis, S. S. (2013). The Effect of Size, Return on Sales, Leverage, Fixed Assets, Industry and Ownership on Effective Tax Rate in the Listed Companies of Tehran Stock Exchange. Interdisciplinary Journal of Contemporary Research, 5(1), 523-528.

Jaafar, A., \& Thornton, J. (2015). Tax Havens and Effective Tax Rates: An Analysis of Private versus Public European Firms. International Journal of Accounting, 50(4), 435-457.

Jensen, M. C., \& Meckling, W. H. (1976). Theory of the Firm: Managerial Behavior, Agency Costs and Ownership Structure. Journal of Financial Economics, 3(4), 305-360.

Marfuah, \& Azizah, A. P. N. (2014). Pengaruh Pajak, Tunneling Incentive dan Exchange Rate pada Keputusan Transfer Pricing. Jurnal Akuntansi dan Auditing Indone- sia, 18(2), 156-165.

Margaretha, F., \& Asmariani, A. (2009). Faktor Faktor Agency Theory yang Mempengaruhi Hutang. Media Riset Bisnis \& Manajemen, 9(1), 1-20.

Nursheha, R. A., Suryarini, T., \& Kiswanto. (2014). FaktorFaktor yang Mempengaruhi Penerimaan Pajak. Accounting Analysis Journal, 3(1), 53-61.

Putri, A., Herawati, \& Hamdi, M. (2018). Pengaruh Tax Minimization, Tunneling Incentive dan Mekanisme Bonus terhadap Keputusan Transfer Pricing. Jurnal Ekonomi, 12(1).

Qiansyah, A. A. (2016). The Influence of Tax Minimization, Tunneling Incentive, Bonus Scheme and Debt Covenant on transfer Pricing Decision: The Indonesian Evidence. Jurnal Ilmiah Mahasiswa Fakultas Ekonomi dan Bisnis, 5(1).

Rego, S. O. (2003). Tax-Avoidance Activities of U.S. Multinational Corporations. Contemporary Accounting Research, 20(4), 805-833.

Richardson, G., Taylor, G., \& Lanis, R. (2013). Determinants of Transfer Pricing Aggressiveness: Empirical Evidence from Australian Firms. Journal of Contemporary Accounting and Economics, 9(2), 136-150.

Sari, E. P., \& Mubarok, A. (2018). Pengaruh Profitabilitas, Pajak dan Debt Convenant Terhadap Transfer Pricing ( Studi Empiris Perusahaan Manufaktur Terdaftar di BEI Tahun 2012-2016 ). Seminar Nasional I Universitas Pamulang, Hal 1-6.

Septiyani, R. P. P., Ramadhanti, W., \& Sudibyo, Y. A. (2018). Some Factors that Affect Transfer Pricing Decision. Soedirman Accounting Review, 03(1), 21-38.

Simanjuntak, D., \& Kiswanto. (2015). Determinan Kebijakan Dividen pada perusahaan Manufaktur di Indonesia. Jurnal Dinamika Akuntansi, 7(2), 150-160.

Suandy, E. (2017). Perencanaan Pajak. Jakarta: Salemba Empat. Talab, H. R., Flayyih, H. H., \& Yassir, Y. N. M. (2017). Transfer Pricing and its Effect on Financial Reporting: A Theoretical Analysis of Global Tax in Multinational Companies. International Business Management, 11(4), 921-928.

Viviany, S. (2018). Pengaruh Tarif Pajak, Tunneling Incentive, Mekanisme Bonus dan Exchange Rate terhadap Transfer Pricing (Studi Empiris pada Perusahaan Manufakturyang Terdaftar di Bursa Efek Indonesia Tahun 2013-2016). Jurnal Online Mahasiswa UNRI, 1(1), 1-15.

Zatun, U. T., \& Kiswanto. (2015). Pengaruh Corporate Governance, Karakteristik Perusahaan terhadap Efisiensi Pembayaran Pajak Melalui Managerial Risk. Accounting Analysis Journal, 4(2), 1-10. 